\title{
MANFAAT TEKNOLOGI INFORMASI DAN KOMUNIKASI DI MASA PANDEMI COVID 19
}

\author{
Rita Komalasari \\ Politeknik LP3I Bandung \\ email: ritakomalasari@plb.ac.id
}

\begin{abstract}
Abstrak : Banyak dari masyarakat menerima begitu saja teknologi informasi dan komunikasi modern yang bahkan tidak dapat diakses beberapa dekade lalu. Inovasiinovasi teknologi informasi dan komunikasi ini, telah lama dianggap sebagai hal sepele, tidak penting, selama masa tenang kini menjadi sangat diperlukan dalam menghadapi pandemi COVID-19. Sekarang telah ada berbagai teknologi digital yang dapat digunakan untuk menambah dan meningkatkan strategi pekerjaan, pembelajaraan dan kesehatan masyarakat. Selama pandemi COVID-19, teknologi memainkan peran penting dalam menjaga kegiatan masyarakat tetap berfungsi pada saat Pembatasan Sosial Berskala Besar (PSBB). Tujuan dari penelitian ini adalah untuk mengetahui bagaimana masyarakat memanfaatkan teknologi informasi dan komunikasi sebagai media untuk meneruskan kegiatan yang tidak dapat dilakukan secara tatap muka dan teknologi yang dapat dimanfaatkan untuk kegiatan medis selama pandemi COVID-19. Metode penelitian ini dipaparkan secara deskriptif kualitatif. Penulis menggunakan teknik pengumpulan data observasi. Hasil yang diperoleh dari penelitian ini masyarakat memanfaatkan teknologi informasi dan komunikasi untuk kegiatan Work From Home, School From Home dan kepentingan informasi untuk Medis. Disimpulkan bahwa masyarakat memanfaatkan saja teknologi informasi dan komunikasi untuk tetap melaksanakan kegiatan karena fasilitas dan fitur dari saja teknologi informasi dan komunikasi yang memiliki keunggulan dan kemudahan untuk dipergunakan oleh berbagai kalangan masyarakat.
\end{abstract}

Kata Kunci : Teknologi Informasi, Komunikasi, Pandemi, Covid-19

\section{Pendahuluan}

Virus Corona (COVID-19) telah melanda sejumlah besar negara dan ternyata menjadi lebih buruk dari masalah ekonomi, strategis dan politik yang kritis terjadi di seluruh dunia. Wabah virus korona telah dan masih berdampak pada semua industri, termasuk penggunaan teknologi informasi dan komunikasi. Pedoman pembatasan jarak sosial yang diajukan oleh masing-masing pemerintah dan departemen kesehatan kepada masyarakat telah menghasilkan penutupan sekolah dan bisnis dan membuat masyarakat bingung menghadapi tingkat perubahan yang belum pernah terjadi sebelumnya. Belajar online dan bekerja dari rumah (Work From Home/WFH) adalah cara untuk menengahi masalah tersebut bagi sebagian masyarakat, tetapi yang lain mungkin tidak seberuntung itu [2].

Perkembangan teknologi informasi yang semakin pesat di era globalisasi saat ini tidak bisa dihindari lagi pengaruhnya terhadap dunia pendidikan. Tuntutan global menuntut dunia pendidikan untuk selalu dan senantiasa menyesuaikan perkembangan teknologi terhadap usaha dalam peningkatan mutu pendidikan, terutama penyesuaian penggunaan teknologi informasi dan komunikasi bagi dunia pendidikan khususnya dalam proses pembelajaran [4]. Tingkat integrasi teknologi atau infus di sekolah/kampus sebelum 
pandemi ini, dapat dieksplorasi dalam hal apakah teknologi digital telah diperkenalkan, diintegrasikan atau dimasukkan ke dalam kebijakan dan praktik pendidikan [1]. Termasuk kesiapan pengajar, infrastruktur Internet, tingkat akses ke laptop, alat online, sumber daya dan penilaian, dan tingkat integrasi ke dalam praktik pengajaran dan pembelajaran sehari-hari.

Untuk beberapa orang, seperti para pemula (individu dengan pengalaman WFH yang terbatas), saat ini mungkin merupakan periode paling intens dari kehidupan profesional yang dapat menjadi langkah perubahan yang belum pernah terjadi sebelumnya. Secara tiba-tiba, terjadi perubahan di seluruh dunia yang berarti semua diminta untuk terlibat dengan kegiatane-learning dan aktivitas online agar dapat melaksanakan tugas berbasis WFH [2].

Dengan penggunaan metode virtual, masalah teknis dipastikan dapat terjadi tetapi dapat dikelola dengan baik ketika pengguna telah menjadi lebih akrab dengan antarmuka virtual. Tantangan utama dari platform WFH atau School From Home (SFH) ini terletak pada kesediaan pengguna untuk merangkul teknologi ini [3].

Tahun 2020 seharusnya menjadi awal dekade yang menarik dalam dunia kedokteran dan sains, dengan berbagai pengembangan beberapa teknologi digital yang dapat diterapkan untuk mengatasi masalah klinis dan penyakit berat. Teknologi digital ini mencakup internet of things (IoT) dengan jaringan telekomunikasi generasi mendatang (mis., 5G) [5][6]; analitik Big Data[7]; kecerdasan buatan (AI) yang menggunakan deep learning [8][9]; dan teknologi blockchain[10]. Teknologi tersebut sangat saling terkait: proliferasi IoT (misalnya, penggunaan perangkat dan instrumen) di rumah sakit dan klinik memfasilitasi pembentukan ekosistem digital yang sangat saling berhubungan, memungkinkan pengumpulan data real-time pada skala, yang kemudian dapat digunakan oleh AI dan sistem deep learning untuk memahami tren perawatan kesehatan, memodelkan asosiasi risiko dan memprediksi hasil. Hal ini ditingkatkan oleh teknologi blockchain, basis data yang terhubung kembali dengan protokol kriptografi dan jaringan komputer terdistribusi di organisasi yang berbeda, mengintegrasikan jaringan peer-topeer untuk memastikan bahwa data disalin di beberapa lokasi fisik, dengan algoritma yang dimodifikasi untuk memastikan data diamankan tetapi dapat dilacak[10].

\section{Metode Penelitian}

Penulis memilih menggunakan metode penelitian kualitatif untuk menentukan cara mencari, mengumpulkan, mengolah dan menganalisis data hasil penelitian tersebut. Penelitian yang digunakan yaitu penelitian kualitatif deskriptif. Penelitian kualitatif deskriptif adalah berupa penelitian dengan metode atau pendekatan studi kasus [11]. Teknik pengumpulan data dilakukan dengan cara observasi.

\section{Pembahasan}

a. Penggunaan teknologi informasi dan komunikasi saat Work From Home

Konsep Work From Home (WFH) merupakan sebuah konsep dimana karyawan suatu perusahaan dapat mengerjakan perkerjaannya dari mana saja, kapan saja. Tetapi dengan adanya pandemi ini memaksa semua perusahaan untuk menerapkan kebijakan WFH bagi hamper semua karyawannya. Beberapa teknologi yang dapat digunakan 
saat WFH adalah teknologi komunikasi pertemuan virtual misalnya aplikasi Zoom atauGoogle Hangouts.

Komunikasi untuk koordinasi antar karyawan secara intens dapat menggunakan media aplikasi Whatsapp Group, aplikasi chatting serta fasilitas video call yang bahkan dapat dipergunakan lebih dari 1 orang lawan bicara memudahkan komunikasi perihal pekerjaan karena terkoneksi secara langsung.

Penggunaan aplikasi Slack bagi perusahaan sangat bermanfaat, dimana slack menawarkan banyak fitur bergaya Internet Relay Chat (IRC), termasuk ruang obrolan (saluran) persisten yang diatur oleh topik, grup pribadi, dan pesan langsung.

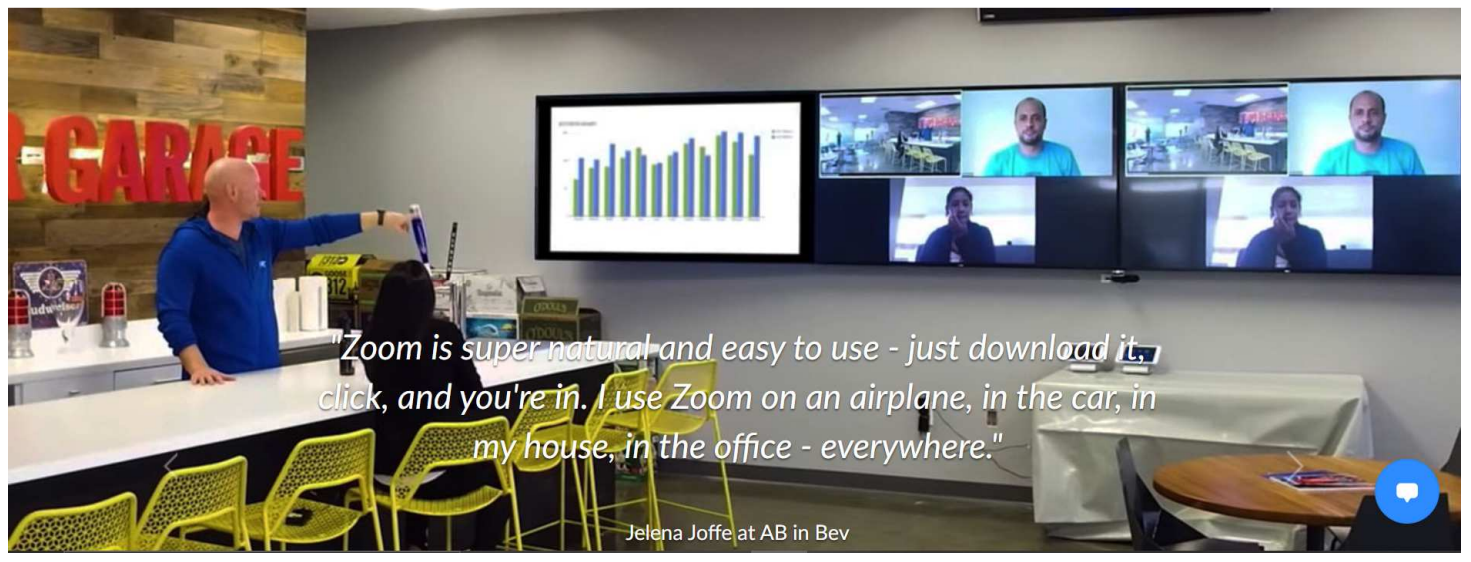

Gambar 1. Pertemuan Virtual menggunakan Zoom

(Sumber : Zoom.us)

Keunggulan penggunaan aplikasi Zoom adalah (a) Panggilan video yang tanpa buffering, penyesuaian otomatis, (b) Panggilan audio - sempurna dan dapat direkam untuk tinjauan di masa mendatang, (c) Panggilan konferensi, dapat dengan mudah menghadirkan 10+ pihak tanpa kehilangan kualitas, (d) Berbagi layar, dapat dengan mudah digunakan, bisa memilih jendela atau monitor apa yang akan dibagikan, (e) Penjadwalan, dapat dengan mudah untuk menjadwalkan acara dan mengekspor ke kalender kemudian mengundang tamu.

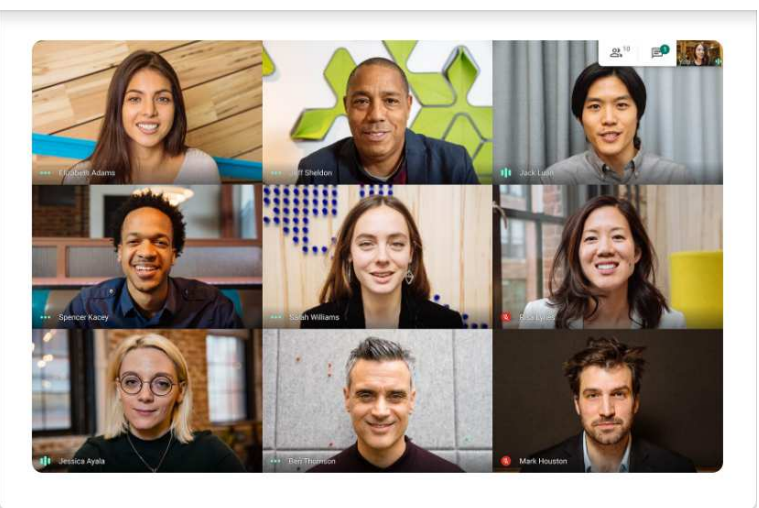

Gambar 2. Pertemuan Virtual menggunakan Google Hangouts

(Sumber : Meet - Googlemeet.google.com) 
Keunggulan penggunaan aplikasi Google Hangouts adalah (a) Gratis. (b) Terintegrasi dengan G Suite. (c) Panggilan video grup. (d) Integrasi server Gmail. (e) Bagus untuk melakukan panggilan telepon. (f) Dapat direkam untuk tinjauan di masa datang. (g) Aplikasi seluler yang ramah pengguna.(h) Dapat menyimpan obrolan untuk referensi di masa mendatang. (i) Mudah untuk menambah dan menghapus kontak. (j) Pengiriman pesan dalam waktu singkat.

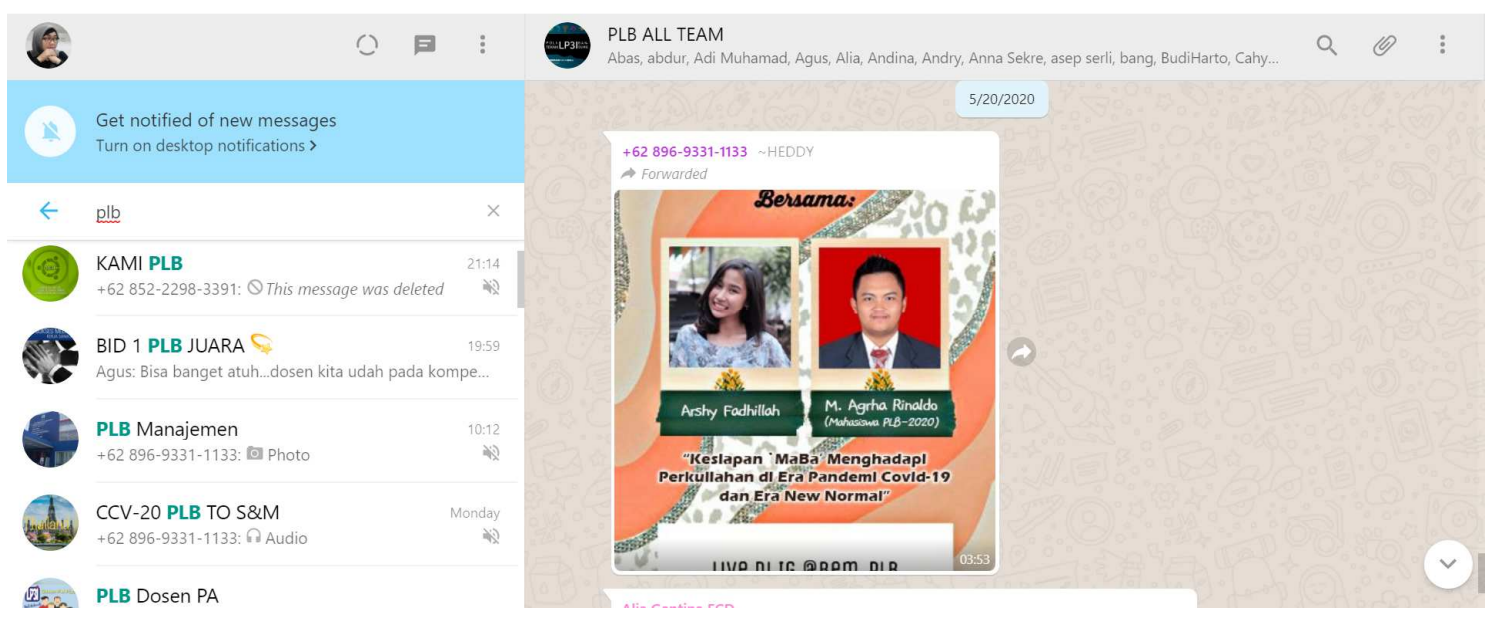

Gambar 3. Aplikasi Whatsapp

Keunggulan penggunaan aplikasi Whatsapp adalah (a) sepenuhnya gratis untuk digunakan. (b) Langsung mengirim pesan. (c) Mudah digunakan. (d) Dukungan panggilan suara dan Panggilan video tersedia. (e) Kirim ke siapa saja. Dokumen file hingga $100 \mathrm{MB}$ seperti PDF dll. (f) menyediakan fitur enkripsi ujung ke ujung, yang membuat komunikasi sangat aman. (g) memperluas layanannya untuk menggunakan browser web langsung dan di Sistem Desktop (Windows, MacOS).

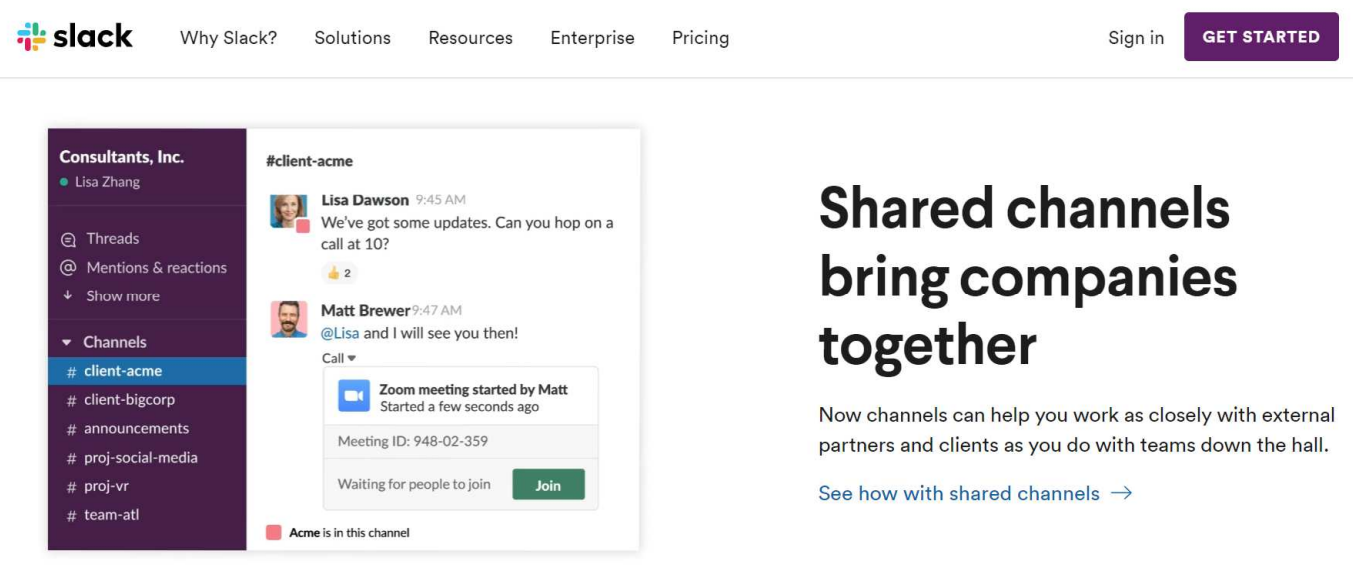

Gambar 4. Shared Channel pada Aplikasi Slack

(Sumber : Slack.com)

Keunggulan penggunaan aplikasi Slack adalah (a) Tim Slack memungkinkan komunitas, grup, atau tim untuk bergabung dengan "ruang kerja" melalui URL atau undangan tertentu yang dikirim oleh admin atau pemilik tim. (b) Saluran publik 
memungkinkan anggota tim untuk berkomunikasi tanpa menggunakan email atau SMS grup (SMS). Saluran publik terbuka untuk semua orang di ruang kerja. Saluran pribadi memungkinkan untuk percakapan pribadi antara sub-kelompok yang lebih kecil. Saluran pribadi ini dapat digunakan untuk mengatur tim besar. Pesan langsung memungkinkan pengguna untuk mengirim pesan pribadi ke pengguna tertentu daripada sekelompok orang. Pesan langsung dapat mencakup hingga sembilan orang. Setelah dimulai, grup pesan langsung dapat dikonversi menjadi saluran pribadi. (c) Slack terintegrasi dengan banyak layanan pihak ketiga dan juga mendukung integrasi yang dibangun komunitas. Integrasi besar termasuk layanan seperti Google Drive, Trello, Dropbox, Box dll. (d) Slack menyediakan aplikasi seluler untuk iOS dan Android selain klien browser Web dan klien desktop untuk macOS, Windows (dengan versi yang tersedia dari situs web perusahaan dan melalui Windows Store) dan Linux (beta).

Pengaturan jadwal untuk selalu dapat memenuhi target pekerjaan dapan menggunakan Google Calendars untuk menjadwalkan tanggal rapat atau mengatur pengingat melalui email.

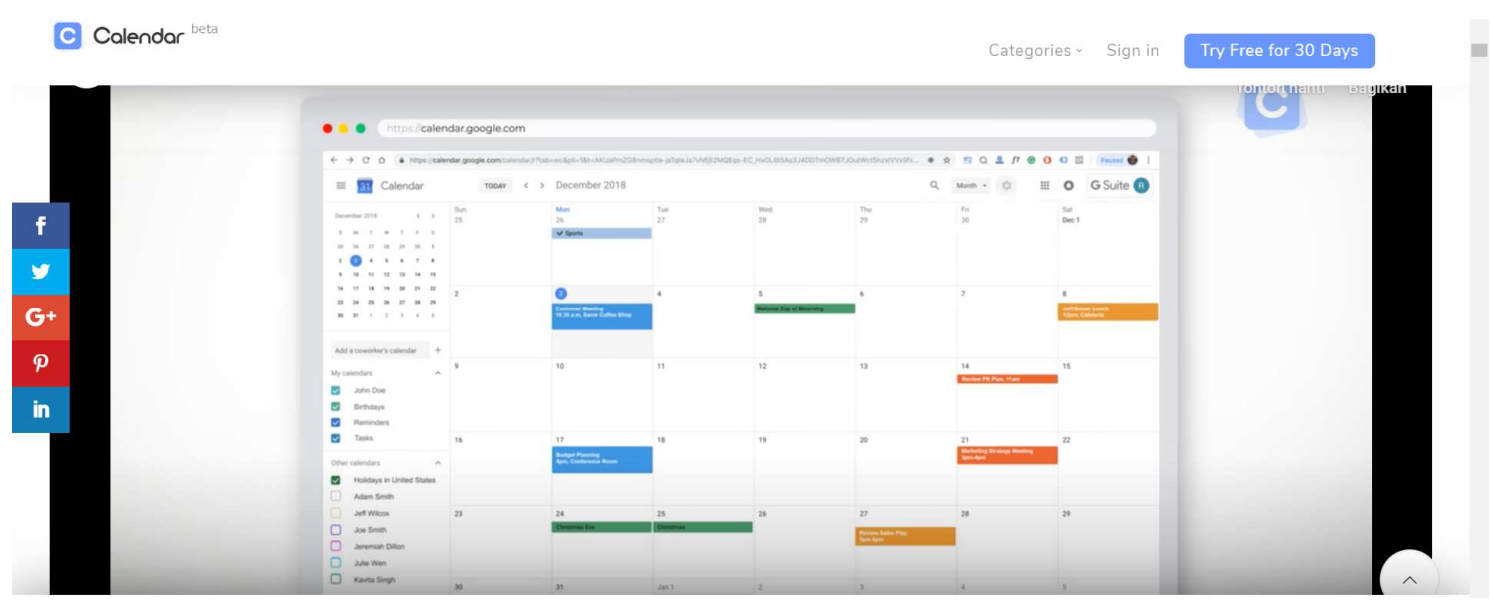

Gambar 5. Aplikasi Google Calendar

(Sumber : Calendar.com)

Keunggulan penggunaan aplikasi Google Calendar adalah (a) Google Calendar memungkinkan pengguna untuk membuat dan mengedit acara. Acara memiliki waktu mulai yang ditetapkan dan waktu berhenti, dengan opsi untuk "Acara sepanjang hari". (b) Pengguna dapat mengaktifkan fungsionalitas "Berulang" dengan parameter opsional untuk frekuensi. (c) Pengguna dapat menambahkan warna ke acara untuk membedakan acara dari yang lain. (d) Acara dapat dilihat dalam berbagai jenis pengaturan, termasuk hari, minggu, bulan, atau jadwal. (e) Lokasi dapat ditambahkan untuk memudahkan pemahaman tentang tempat acara. (f) Pengguna secara opsional dapat mengatur pemberitahuan, dengan opsi untuk jenis (email, pemberitahuan push seluler) dan waktu. (g) Pengguna dapat mengundang orang lain ke acara; untuk pengguna Google Calendar lainnya, acara tersebut menjadi terlihat di kalender mereka, dan untuk pengguna non-Kalender Google, email akan memiliki opsi untuk "Ya", "Tidak", atau "Mungkin". (h) Pengaturan privasi memungkinkan pengguna untuk menentukan tingkat visibilitas publik dari seluruh kalender atau peristiwa individual. Meskipun kalender default untuk menampilkan waktu acara pengguna dalam waktu 
lokal mereka, pengguna dapat menentukan zona waktu yang berbeda untuk suatu acara. (i) Pengguna dapat mengaktifkan atau menonaktifkan visibilitas kalender khusus, termasuk kalender Ulang Tahun, yang secara otomatis mengambil tanggal kelahiran dari kontak Google pengguna dan menampilkan tanggal secara tahunan, dan kalender Liburan, kalender khusus negara yang menampilkan tanggal khusus kesempatan. [12]

Penyimpanan dokumen secara bersama di perusahaan dapat menggunakan penyimpanan berbasis cloud, misalnya Google Drive yang mempunyai keunggulan dapat menyimpan foto, cerita, desain, gambar, rekaman, video, dan lain-lain dengan ruang penyimpanan 15 GB pertama gratis dengan Akun Google.

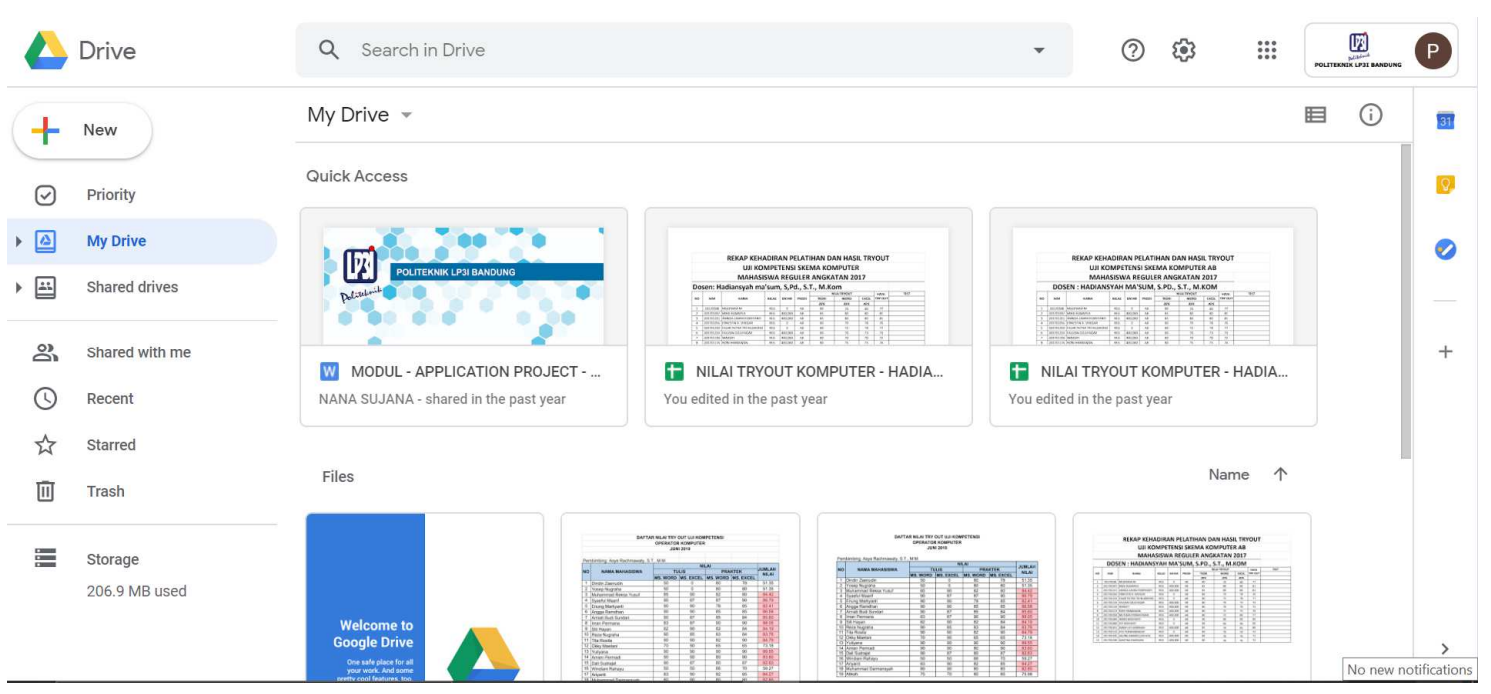

Gambar 6. Aplikasi Google Drive

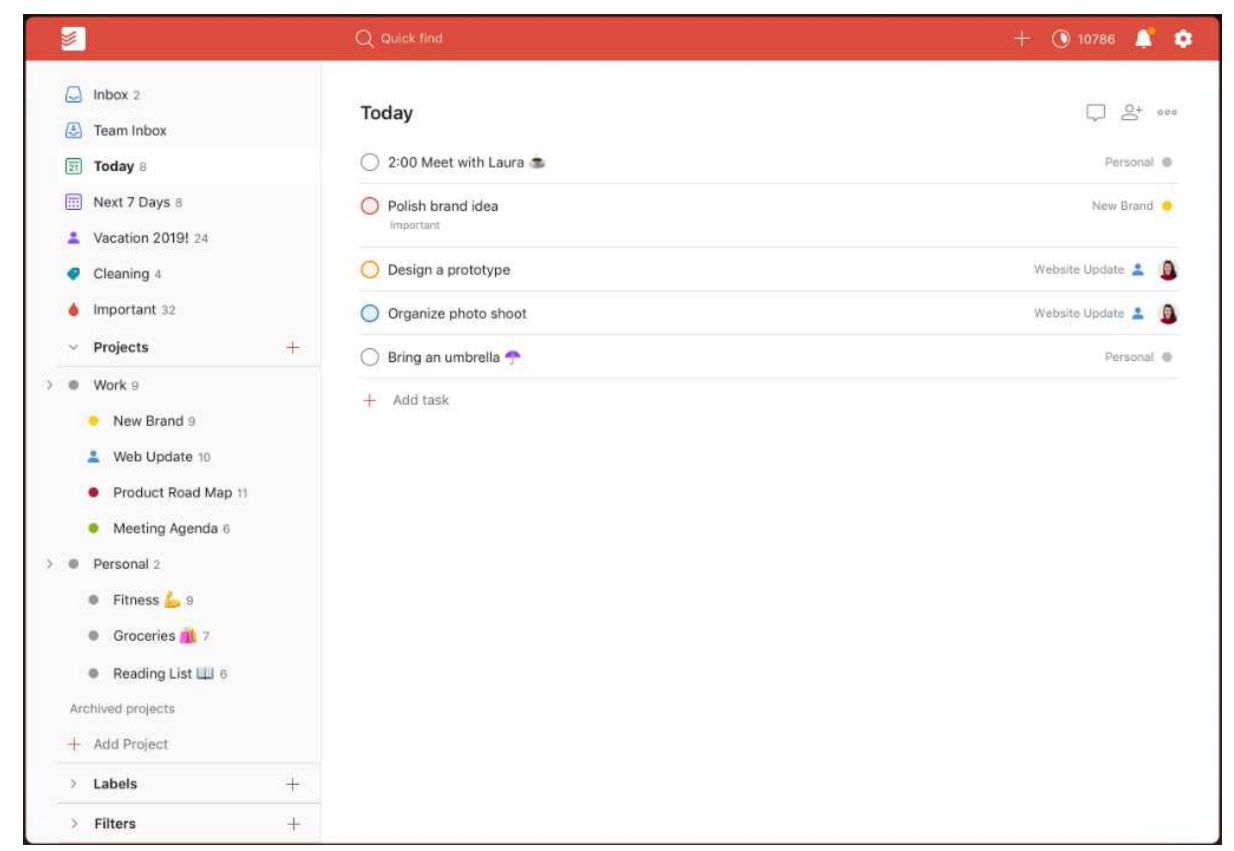

Gambar 6. Aplikasi Todoist

(Sumber : Todoist.com) 
Aplikasi Todoist dapat digunakan karyawan untuk memilah pekerjaan sesuai dengan prioritasnya dan membantu pengaturan waktu. Keunggulan penggunaan aplikasi Todoist adalah (a) pengingat tenggat waktu dengan pengingat dan tanggal jatuh tempo. (b) membantu untuk membangun kebiasaan dengan tanggal jatuh tempo berulang seperti "setiap hari Senin". (c) Berkolaborasi pada proyek dengan menugaskan tugas kepada orang lain. (d) Prioritaskan tugas berdasarkan tingkat prioritas. (e) melacak kemajuan pekerjaan dengan tren produktivitas hasil personalisasi.

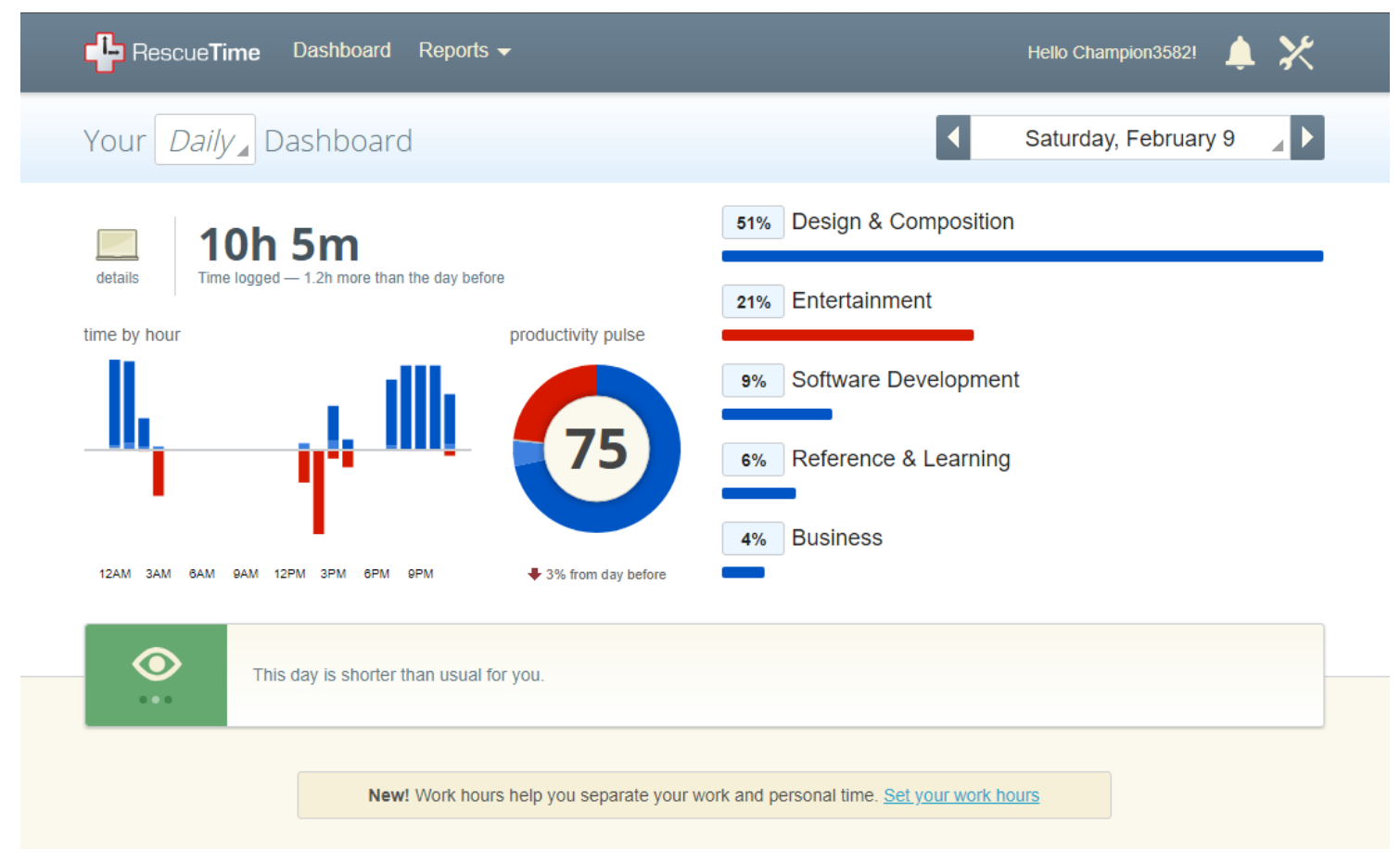

Gambar 7. Aplikasi RescueTime

(Sumber : Medium.com)

RescueTime merupakan perangkat lunak pelacak waktu dan gangguan pengalihan perhatian dengan memberi alat dan data yang dibutuhkan untuk menjadi karyawan yang paling produktif. Keunggulan penggunaan aplikasi RescueTime adalah (a) Perangkat lunak pemblokiran gangguan. (b) Alat analisis dan pelaporan: Perangkat lunak pelacakan waktu otomatis untuk melacak waktu yang digunakan di situs dan aplikasi. (c) melihat kemajuan karyawan dalam laporan email mingguan. (d) Bekerja lintas platform (desktop, seluler, browser). (e) Pelacakan waktu offline. (f) Sorotan harian. (g) Jam kerja khusus. (h) Data historis tidak terbatas.

b. Penggunaan teknologi informasi dan komunikasi saat School From Home

Pemanfaatan aplikasi belajar online menjadi solusi bagi sekolah-sekolah yang mulai menerapkan sistem School From Home. Sebagai salah satu perusahaan edutech di Indonesia, Quipper menyediakan sistem dan materi pembelajaran online secara gratis untuk guru dan siswa. dimana guru dapat memanfaatkan fitur LMS (learning management system) milik Quipper untuk mengirim dan mengelola materi 
pembelajaran, ujian, serta nilai siswa, sehingga memungkinkan guru untuk mengajar secara jarak jauh. [13]

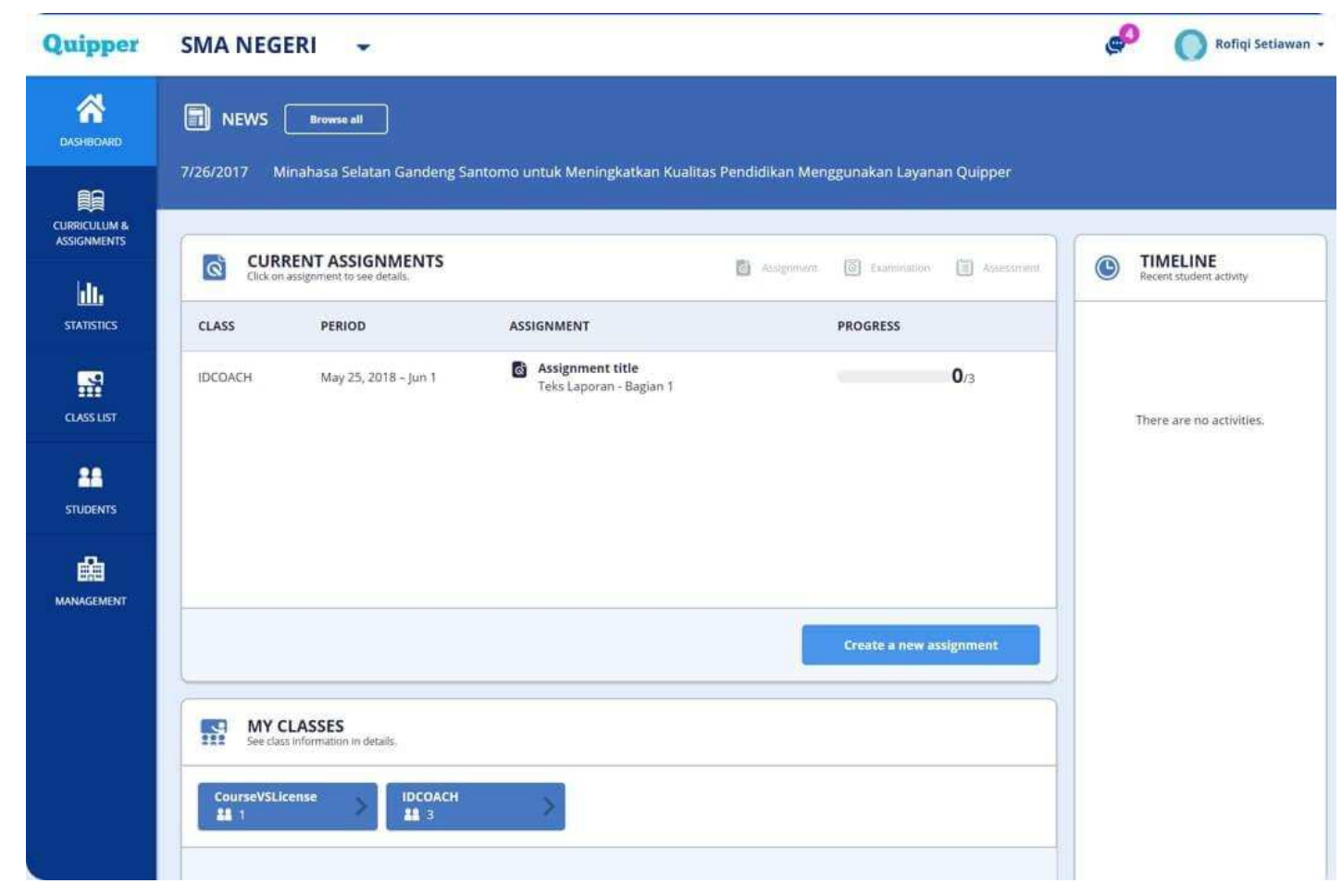

\section{Gambar 8. Aplikasi Quipper}

(Sumber : Quipper.com)

Ruangguru mengembangkan berbagai layanan belajar berbasis teknologi, termasuk layanan kelas virtual, platform ujian online, video belajar, serta konten-konten pendidikan lainnya yang bisa diakses melalui web dan aplikasi Ruangguru.

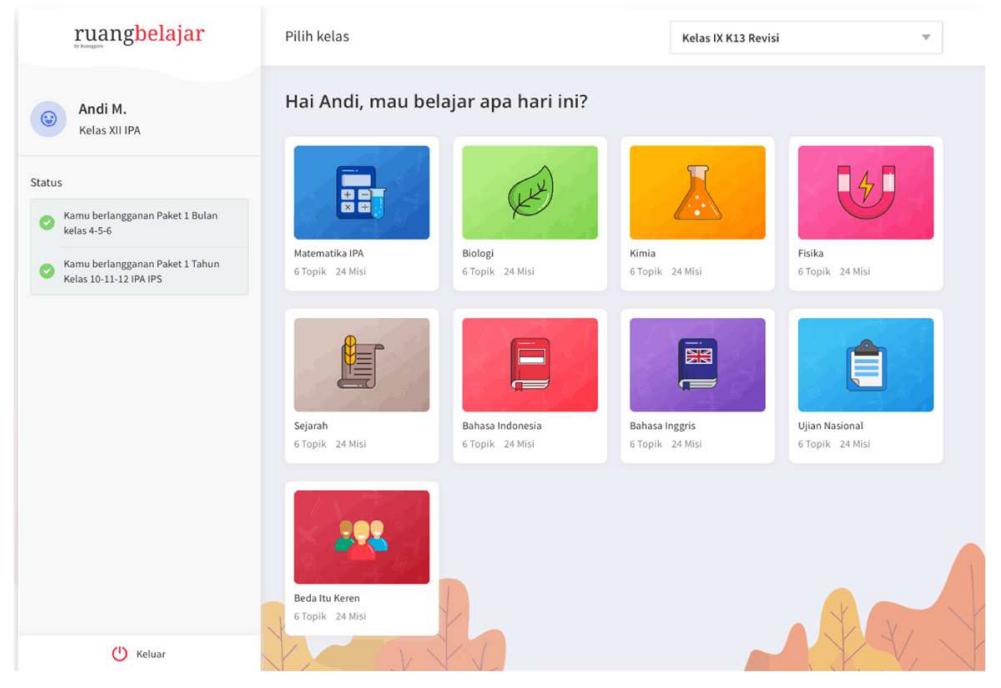

Gambar 9. Aplikasi Ruangguru

(Sumber : Ruangguru.com) 
Aplikasi pembelajaran Zenius menyediakan akses ke bank latihan soal untuk bahan pembelajaran mandiri siswa. Guru pun dapat turut membagikan konten berupa video pembelajaran dan latihan soal tersebut kepada siswa dan orang tua murid melalui berbagai platform media sosial yang ada, seperti grup WhatsApp. Sesi pengajaran kelas online Zenius dipandu oleh tutor Zenius dari berbagai mata pelajaran dan disiarkan secara langsung. Lebih dari itu, kelas online Zenius juga dilengkapi dengan fitur Live Chat, sehingga siswa dapat berinteraksi dan memberikan pertanyaan kepada tutor saat proses pengajaran berlangsung.

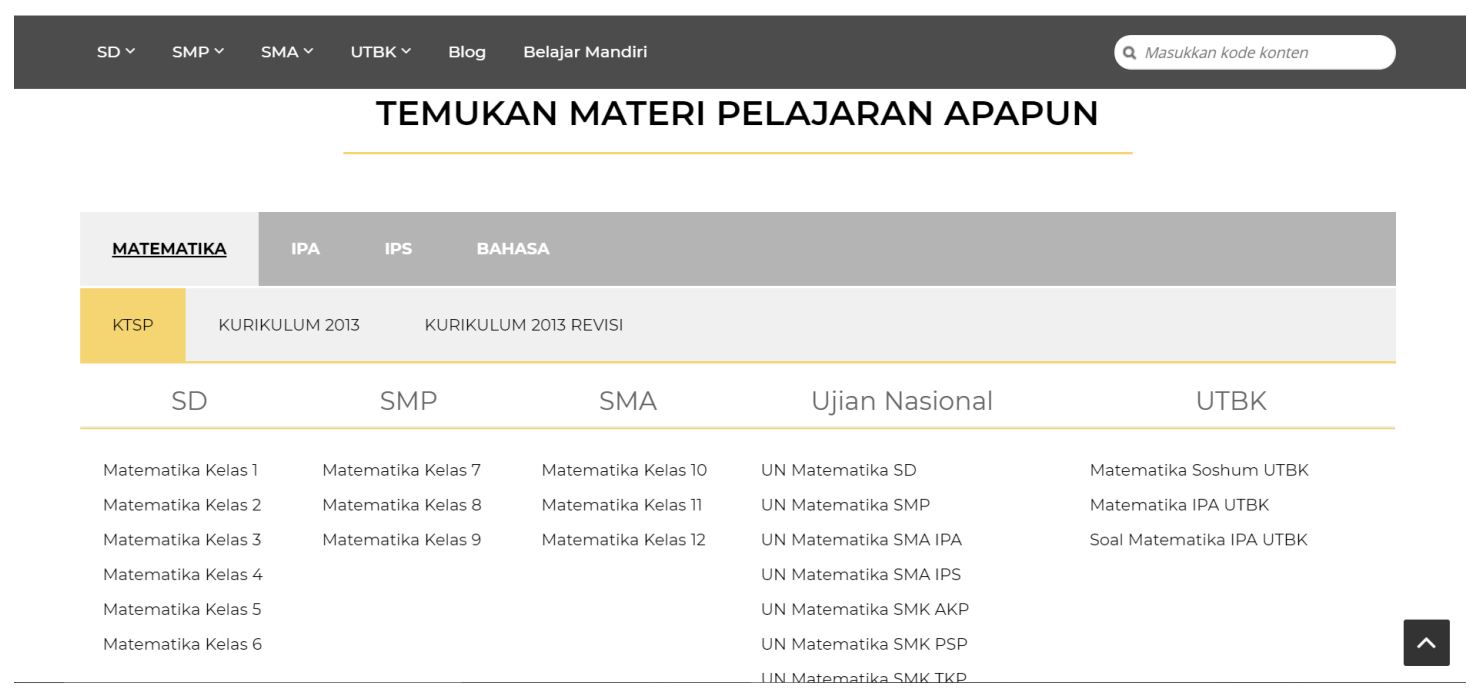

Gambar 10. Aplikasi Zenius

(Sumber : Zenius.Net)

Selain sekolah, perguruan tinggi pun saat ini melaksanakan kegiatan pembelajaran jarak jauh menggunakan berbagai fasilitas yang tersedia, misalnya menggunakan aplikasi elearning yang telah tersedia di Sistem Akademik.

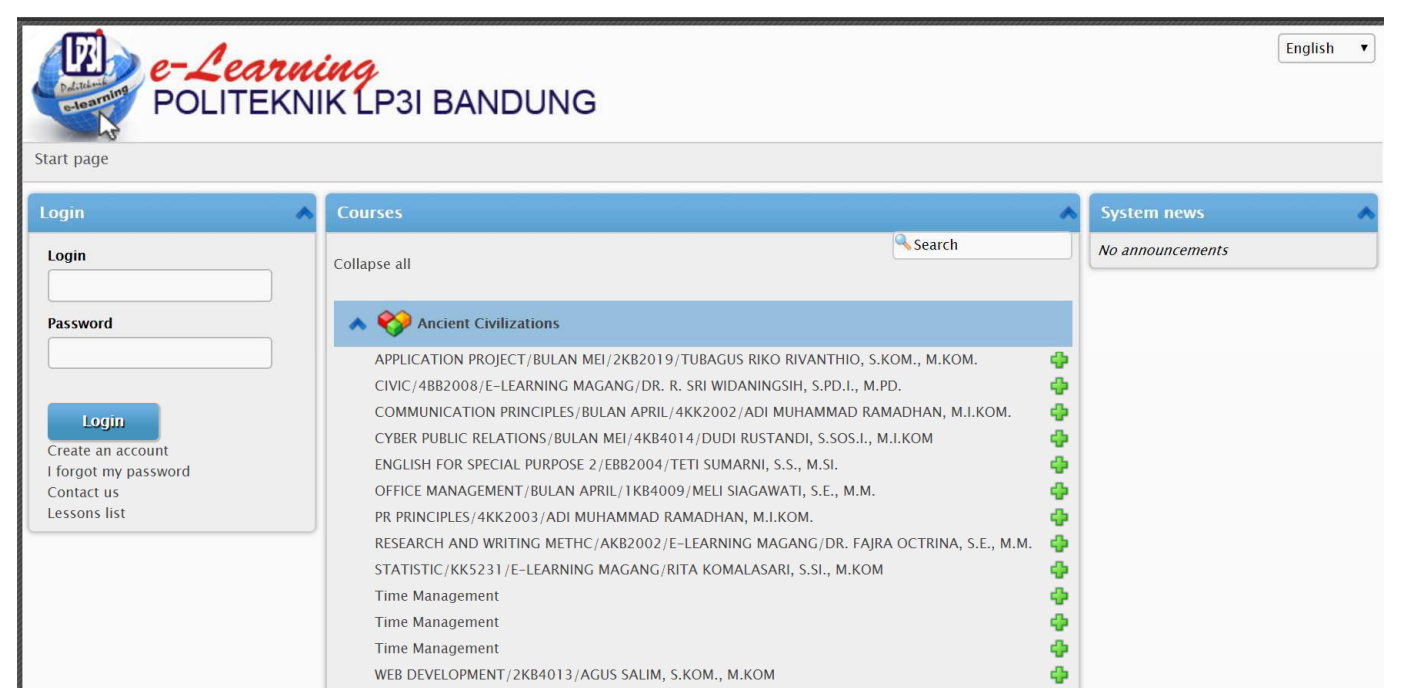

Gambar 10. Aplikasi Elearning Politeknik LP3I 
Selain LMS yang telah dibuat oleh kampus, Dosen pun berinisiatif menggunakan aplikasi Google Classroom untuk menunjang pembelajaran interaktif dengan mahasiswa

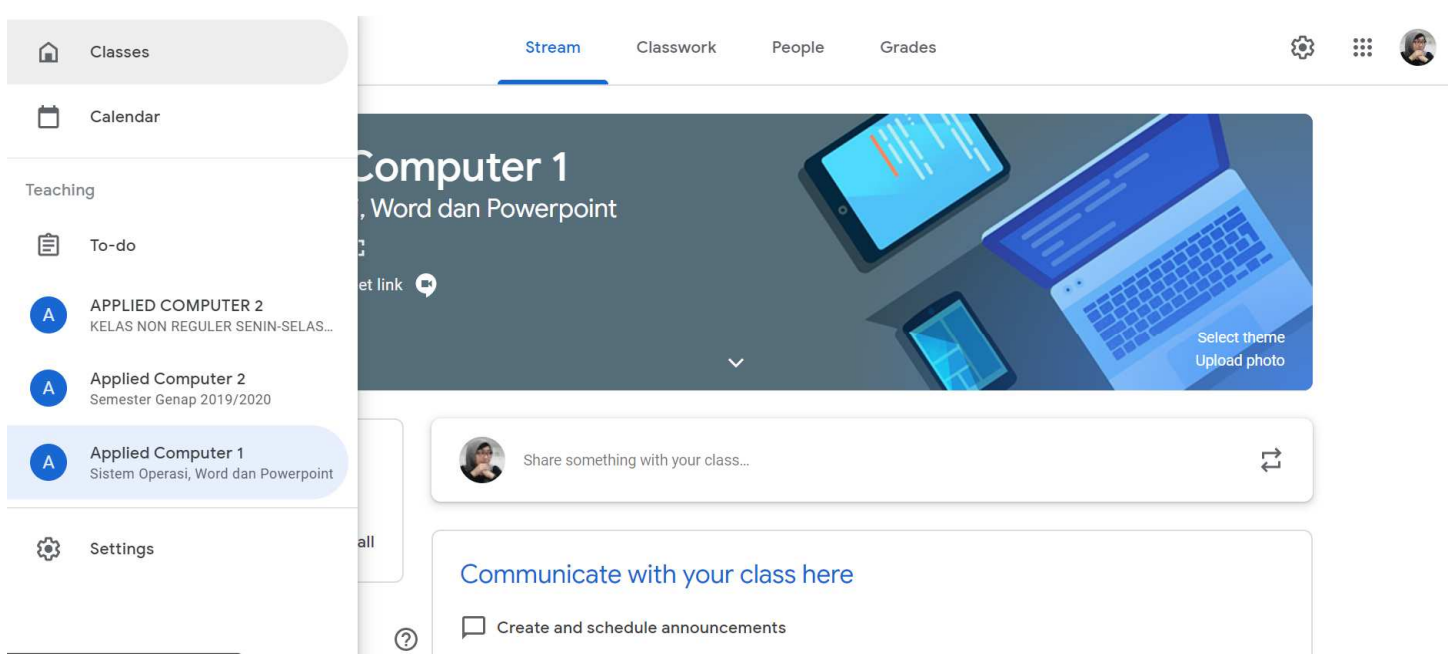

Gambar 11. Aplikasi Google Classroom

c. Penggunaan teknologi informasi dan komunikasi untuk kepentingan medis

IoT menyediakan platform yang memungkinkan lembaga kesehatan masyarakat mengakses data untuk memantau pandemi COVID-19. Misalnya, 'Worldometer' menyediakan pembaruan real-time tentang jumlah sebenarnya orang yang diketahui memiliki COVID-19 di seluruh dunia, termasuk kasus baru harian penyakit, distribusi penyakit oleh negara-negara dan tingkat keparahan penyakit (pulih, kondisi kritis atau kematian).

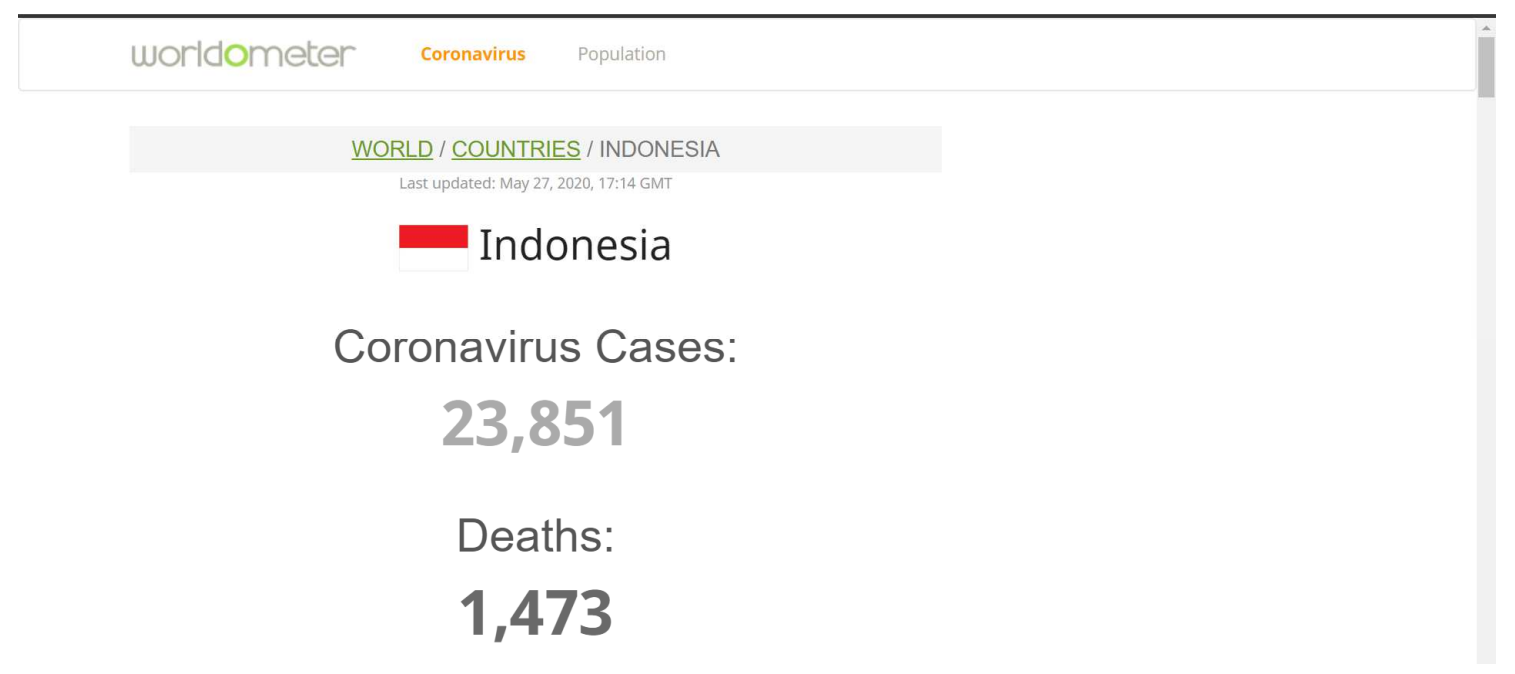

Gambar 11. Aplikasi Worldometer

Big Data juga memberikan peluang untuk melakukan studi pemodelan aktivitas virus dan untuk membimbing pembuat kebijakan kesehatan negara atau individu untuk meningkatkan persiapan untuk wabah. Menggunakan tiga basis data global - 
Panduan Penerbangan Resmi, layanan berbasis lokasi dari Tencent (Shenzhen, Cina), dan Biro Manajemen Transportasi Kota Wuhan - Wu et al. melakukan studi model 'nowcasting' dan meramalkan aktivitas penyakit COVID-19 di dalam dan di luar China yang dapat digunakan oleh otoritas kesehatan untuk perencanaan dan kontrol kesehatan publik di seluruh dunia [14].

Teknologi digital dapat meningkatkan pendidikan dan komunikasi kesehatan masyarakat. Beberapa platform media sosial (mis., Facebook dan Twitter) saat ini digunakan oleh agen kesehatan untuk memberikan pembaruan real-time dan memperjelas ketidakpastian dengan publik. Selain itu, beberapa perusahaan pengenalan wajah (mis., SenseTime dan Sunell) telah mengadopsi pengenalan wajah yang mengaktifkan pencitraan termal untuk mengidentifikasi orang-orang dengan suhu tinggi di berbagai titik skrining di Tiongkok.

(https://apnews.com/PR\%20Newswire/354aae0738073bc95331ee72a458cb50).

AI dan deep learning dapat meningkatkan deteksi dan diagnosis COVID-19. Kebutuhan untuk menyediakan akses ke tes yang akurat dan berbiaya rendah untuk diagnosis COVID-19 adalah sebuah tantangan bagi para peneliti. Dalam konteks ini, Cina memiliki kumpulan data set kasus positif untuk COVID-19 (> 70.000 kasus). Ini adalah kumpulan data yang ideal untuk AI dan deep learning (https://www.wired.com/story/chinese-hospital-deploy-ai-help-diagnose-covid-19/).

Algoritma AI tersebut kemudian dapat digunakan sebagai alat skrining awal untuk kasus yang dicurigai (misalnya, riwayat perjalanan ke China, Iran atau Korea Selatan, atau paparan terhadap kasus yang dikonfirmasi) sehingga pasien dengan risiko lebih tinggi dapat menjalani tes berbasis laboratorium konfirmasi atau diisolasi.

\section{Kesimpulan}

Banyak dari masyarakat menerima begitu saja teknologi digital modern yang bahkan tidak dapat diakses beberapa dekade lalu. Inovasi-inovasi teknologi ini, yang telah lama ditandai sebagai hal sepele, tidak penting, atau bahkan berbahaya selama masa tenang kini menjadi sangat diperlukan dalam menghadapi pandemi COVID-19. Sekarang telah ada berbagai teknologi digital yang dapat digunakan untuk menambah dan meningkatkan strategi pekerjaan, pembelajaraan dan kesehatan masyarakat. Selama pandemi COVID19, teknologi memainkan peran penting dalam menjaga kegiatan masyarakat tetap berfungsi pada saat Pembatasan Sosial Berskala Besar (PSBB).

\section{Daftar Pustaka}

[1] Starkey, L. (2020). A review of research exploring teacher preparation for the digital age. Cambridge Journal of Education, 50 1, 37-56.

[2] Jessica Li, Rajashi Ghosh \& Stefanos Nachmias (2020) In a time of COVID-19 pandemic, stay healthy, connected, productive, and learning: words from the editorial team of HRDI, Human Resource Development International, 23:3, 199-207, DOI: 10.1080/13678868.2020.1752493

[3] Almarzooq, Zaid \& Lopes, Mathew \& Kochar, Ajar. (2020). Virtual Learning during the COVID-19 Pandemic: A Disruptive Technology in Graduate Medical Education. Journal of the American College of Cardiology. 10.1016/j.jacc.2020.04.015. 
[4] Haris Budiman, (2017). Peran teknologi informasi dan komunikasi dalam pendidikan. Al-Tadzkiyyah: Jurnal Pendidikan Islam, (8), 75-83

[5] Perkel, J. M. (2017). The Internet of Things comes to the lab. Nature 542, 125-126.

[6] Ting, D. S. W., Lin, H., Ruamviboonsuk, P., Wong, T. Y. \& Sim, D. A. (2019). Artificial intelligence, the internet of things, and virtual clinics: ophthalmology at the digital translation forefront. Lancet Digital Health (2), E8-E9. DOI: https://doi.org/10.1016/S2589-7500(19)30217-1

[7] Shilo, S., Rossman, H. \& Segal, E. (2020). Axes of a revolution: challenges and promises of big data in healthcare. Nat Med 26, 29-38 https://doi.org/10.1038/s41591-019-0727-5.

[8] LeCun, Y., Bengio, Y. \& Hinton, G. (2015). Deep learning. Nature 521, 436-444. https://doi.org/10.1038/nature14539

[9] Ting, D.S.W., Liu, Y., Burlina, P. et al. (2018). AI for medical imaging goes deep. Nat Med 24, 539-540. https://doi.org/10.1038/s41591-018-0029-3.

[10] Heaven, D. (2019). Bitcoin for the biological literature. Nature 566, 141-142

[11] Sugiyono. (2017). Metode Penelitian Kuantitatif, Kualitatif, dan R\&D. Bandung : Alfabeta, CV

[12] "Google Calendar Desktop App for Windows 10/Mac - An Ultimate Guide". osjoy.com. Dilihat 27 Mei 2020

[13] https://jurnalapps.co.id/sepekan-penerapan-school-from-home-20-000-kelasonline-quipper-digunakan-guru-untuk-belajar-mengajar-18784. Dilihat 27 Mei 2020

[14] Wu, J. T., Leung, K. \& Leung, G. M. (2020). Nowcasting and forecasting the potential domestic and international spread of the 2019-nCoV outbreak originating in Wuhan, China: a modelling study. Lancet 395, 689-697 DOI:https://doi.org/10.1016/S0140-6736(20)30260-9 